\title{
ANALISIS PENYELESIAN SENGKETA INTERNAL LEMBAGA NEGARA (STUDI KASUS PELANTIKAN PIMPINAN DEWAN PERWAKILAN DAERAH REPUBLIK INDONESIA PERIODE 2017-2019)
}

\author{
Yanzah Bagas Nugraha \\ (Mahasiswa Program S1 Fakultas Hukum Universitas Tarumanagara) \\ (Email: yanzahbagasnugraha@yahoo.com)
}

\section{Dwi Andayani Budisetyowati}

(Corresponding Author)

(Dosen Hukum Tata Negara Fakultas Hukum Universitas Tarumanagara. Meraih Gelar Sarjana

Hukum Dari Fakultas Hukum Universitas Gadjah Mada, Gelar Magister Hukum Dari Fakultas

Hukum Universitas Indonesia, Gelar Doktor Hukum Dari Fakultas Hukum Universitas Indonesia)

\begin{abstract}
The establishment of the Regional Representative Council of the Republic of Indonesia so called Dewan Perwakilan Daerah (DPD-RI) at least has two objectives. The first is to enhance justice for the people in the region. Secondly, to expanding and increasing the participation of local communities in national life. The process to form this state institution is done by amending the 3rd amendment of the 1945 Constitution of the Republic Indonesia. However, in doing that amendment there was an internal conflict within the body of DPD-RI involving the old and the new leaders of this institution last year. The length of leadership tenure which was initially made 5 years was amended to became 2.5 years. The different length of leadership tenure was then canceled by the Supreme Court and it was decided to be the same as other institution such as The People's Consultative Assembly and The House of Representative in that the leadership tenure should be in accordance with the electoral cycle of 5 years. However, although the regulation of DPD-RI has been canceled, the Supreme Court keeps sending its representative to guide the oath of position of the new DPD-RI leadership. The only regulation that has been introduced by the state was regulation toward conflict between state institutions and this conflict can merely be resolved by the Constitutional Court. Therefore, there is an urgent need for the state to seek solution to solve this problem to prevent the same thing happened to other state institution in the future.
\end{abstract}

Keywords : Regional People's Representative Assembly, Supreme Court, Constitutional Court 


\section{Pendahuluan}

\section{A. Latar Belakang}

Sejalan dengan tuntutan demokrasi guna memenuhi rasa keadilan masyarakat di daerah, memperluas serta meningkatkan semangat dan kapasitas partisipasi daerah dalam kehidupan nasional serta untuk memperkuat Negara Kesatuan Republik Indonesia, maka dalam pembaharuan konstitusi, MPR RI membentuk sebuah lembaga perwakilan baru, yakni Dewan Perwakilan Daerah (DPD RI). Pembentukkan DPD RI ini dilakukan melalui perubahan ketiga Undang-Undang Dasar Negara Kesatuan Republik Indonesia Tahun 1945 (yang selanjutnya disingkat menjadi UUD NRI Tahun 1945) mengenai pemerintahan daerah.

Beberapa waktu belakangan ini terjadi kegaduhan dalam tubuh DPD RI. Putusan Mahkamah Agung soal tata tertib DPD terkait masa jabatan pimpinan DPD menjadi polemik. Putusan Mahkamah Agung Nomor 20 P/HUM/2017 membatalkan Tata Tertib Nomor 1 Tahun 2017 yang mengatur mengenai masa jabatan Pimpinan DPD RI selama 2 tahun 6 bulan telah melanggar Undang-Undang MD3 Pasal 260 ayat (1) yang hanya mengatur mengenai tata cara pemilihan Pimpinan DPD RI dan bukan mengenai masa jabatan Pimpinan DPD RI. Pasal 323 Peraturan DPD-RI Nomor 1 Tahun 2017 tersebut, dimana masa jabatan pimpinan yang tadinya 2014-2019, berubah menjadi 2014-2017 dan 2017-2019 sesungguhnya adalah pemberlakuan surut. Ketentuan Undang-Undang Nomor 12 Tahun 2011 tentang Pembentukan Peraturan Perundang-undangan pada prinsipnya melarang pemberlakuan surut suatu peraturan perundang-undangan.

Adanya tata tertib tersebut, maka masa jabatan Mohammad Saleh selaku ketua serta Farouk Muhammad dan GKR Hemas selaku wakil ketua, dianggap kembali normal dan berakhir pada 2019 sesuai siklus pemilu, pertimbangan putusan Mahkamah Agung Nomor 20P/HUM/2017, majelis menyatakan DPD satu rumpun dengan MPR dan DPR. Oleh karena itu, masa jabatan pimpinan DPD ditetapkan sama dengan masa jabatan pimpinan lembaga tinggi lainnya. Majelis juga mengingatkan bahwa 
pengabdian tertinggi anggota DPD seharusnya kepada bangsa dan negara, bukan pada kelompok tertentu.

Meski sudah membuat putusan, MA tetap mengirimkan perwakilan untuk memandu pengucapan sumpah jabatan tiga pimpinan DPD, yakni Oesman Sapta Odang sebagai Ketua DPD serta Nono Samponodan Darmayanti Lubis sebagai Wakil Ketua DPD. ${ }^{1)}$ Kaitannya dengan pengambilan sumpah atau janji Pimpinan DPD, Pasal 260 ayat (6) UndangUndang MD3 menegaskan bahwa Ketua Mahkamah Agung berperan memandu pengucapan sumpah atau janji Pimpinan DPD.

Jika dilihat dari sudut hukum tentunya pelantikan pimpinan DPD RI yang baru tidak memiliki legalitas hukum, meskipun seperti itu tetapi roda pemerintahan DPD RI tetap berjalan sampai dengan saat ini dengan di ketuai oleh pimpinan yang tidak mempunyai kedudukan di mata hukum. Seorang pimpinan yang telah mengetahui masa jabatan yang ia jalani berjalan selama 5 tahun tetapi tiba-tiba harus turun dari jabatannya, pastinya mempunyai permasalahan hukum yang luar biasa. Jika permasalahan ini kembali terjadi lagi sewaktu-waktu, maka akan sulit untuk menyelesaikannya di karenakan belum ada lembaga negara yang mampu untuk menyelesaikan sengketa kewenangan didalam lembaga itu sendiri, hal ini tentunya berbeda apabila yang bersengketa melibatkan antar lembaga negara.

\section{B. Metodologi Penulisan}

Jenis penelitian yang digunakan oleh peneliti dalam penelitian ini yaitu penelitian secara yuridis normatif, yaitu dilakukan berdasarkan bahan hukum utama dengan cara menelaah teori-teori, konsep-konsep, asas-asas hukum serta peraturan perundang-undangan yang berhubungan dengan penelitian ini, menggunakan penelitian hukum yuridis normatif karena dalam penelitian ini tidak menggunakan data statistik.

\footnotetext{
${ }^{1)}$ Rakhmat Nur Hakim, “ Ini Putusan MA Soal Tata Tertib Terkait Kursi Pimpinan DPD ",http://nasional.kompas.com, 1 Februari 2018, hal. 1.
} 
Penelitian hukum normatif seringkali juga diklasifikasikan sebagai penelitian kualitatif. Perbedaan antara penelitian kualitatif dan penelitian kuantitatif adalah pada sifat data, karena penelitian itu menyangkut data dan konsekuensinya pada analisisnya. Kesalahan terhadap penelitian hukum ialah karena penelitian hukum normatif tidak menggunakan analisis kuantitatif (statistik), serta merta penelitian hukum dikualifikasikan sebagai penelitian kualitatif.

Kegunaan metode penelitian hukum normatif ialah sebagai berikut: ${ }^{2)}$

a. Untuk mengetahui atau mengenal apakah dan bagaimanakah hukum positifnya mengenai suatu masalah yang tertentu dan ini merupakan tugas semua sarjana hukum.

b. Untuk dapat menyusun dokumen-dokumen hukum yang diperlukan oleh masyarakat.

c. Untuk menulis makalah atau ceramah atau buku hukum.

d. Untuk dapat menjelaskan atau menerangkan kepada orang lain apakah dan bagaimanakah hukumnya mengenai peristiwa atau masalah yang tertentu.

e. Untuk melakukan penelitian dasar di bidang hukum, khususnya apabila kita mencari asas hukum, teori hukum, dan siatem hukum, terutama dalam hal penemuan dan pembentukkan asas-asas hukum baru, pendekatan hukum yang baru, dan sistem hukum nasional.

f. Untuk menyusun rancangan Undang-Undang, atau peraturan Perundang-Undangan yang baru.

g. Untuk menyusun rencana-rencana pembangunan hukum.

Dalam menganalisis permasalahan ini, penulis menggunakan metode deduktif, Metode deduksi berpangkal dari premis mayor (pernyataan yang bersifat umum). Kemudian diajukan premis minor (bersifat khusus), dari kedua premis tersebut kemudian ditarik kesimpulan. ${ }^{3)}$ Penelitian ini menggunakan teknis analisis deduktif, pada prosedur ini, kebenaran pangkal merupakan kebenaran ideal yang bersifat aksiomatik (self evident) yang esensi kebenarannya

\footnotetext{
${ }^{2)}$ Sunaryati Hartono, Penelitian Hukum di Indonesia Pada Akhir Abad ke-20, (Bandung: Alumni, 1994), hal. 140.

${ }^{3)}$ Philipus M. Hadjon dan Tatiek Sri Djamiati, Argumentasi Hukum, (Yogyakarta: Gajah Mada University Press, 2005), hal. 47.
} 
sudah tidak diperlukan lagi. ${ }^{4)}$ Berdasarkan hal tersebut, dalam penelitian ini akan melakukan telaah terhadap peraturan perundangundangan yang saling berkaitan. Mentelaah pengertian-pengertian dasar dari sistem hukum yang terdapat di dalam peraturan perundangundangan tersebut, hal pertama yang harus dilakukan adalah mengumpulkan peraturan perundang-undangan yang menjadi pusat penelitian dari peneliti. Kemudian di adakan suatu analisa, dengan mempergunakan pengertian-pengertian dasar dari sistem hukum, yang lazimnya mencakup::

a. Subyek hukum,

b. Hak dan kewajiban,

c. Peristiwa hukum,

d. Hubungan hukum

e. Obyek hukum.

Analisa hanya dilakukan terhadap pasal-pasal yang isinya merupakan kaedah (hukum). Setelah dilakukan analisa, maka kontruksi dilaksanakan dengan cara memasukkan pasal-pasal tertentu, ke dalam kategori-kategori atas dasar pengertian-pengertian dasar dari sistem hukum tersebut. ${ }^{6)}$

\section{Rumusan Masalah}

Terhadap latar belakang yang sudah dijelaskan, maka akan di angkat isu hukum yang permasalahannya yaitu, bagaimana penyelesaian sengketa internal lembaga negara seperti yang terjadi dalam tubuh DPD-RI?

\section{Tinjauan Pustaka}

1. Tinjauan Umum mengenai Penyelesaian Sengketa Lembaga Negara

\footnotetext{
${ }^{4)}$ Bambang Sunggono, Metodologi Penelitian Hukum, Cetakan ke-6. (Jakarta:Raja Grafindo, 2003), hal 11.

${ }^{5)}$ Soerjono Soekanto, Pengantar Penelitian Hukum, (Jakarta: Universitas Indonesia, 2006), hal. 255 .

${ }^{6)}$ Ibid., hal. 255.
} 
Ketidakjelasan dalam pola hubungan antarlembaga negara, telah melahirkan implikasi lanjutan berupa potensi sengketa kewenangan antar lembaga negara.

"Potensi sengketa ini baik antarlembaga negara independen yang basis kewenangan keduanya ada di konstitusi; kewenangannya tidak dituliskan di konstitusi, lembaga negara yang kewenangannya ada di konstitusi dengan yang tidak dituliskan di dalam konstitusi; atau bisa juga dalam bentuk sengketa kewenangan antar lembaga negara independen dengan lembaga pemerintahan.,"7)

Pada 13 Agustus 2003 dikeluarkanlah Undang-Undang No. 24 Tahun 2003 tentang Mahkamah Konstitusi. UU ini merupakan pelaksanaan amanat Pasal 24C ayat (6) UUD NRI Tahun 1945. Salah satu amanat konstitusional yang dilimpahkan oleh UUD NRI Tahun 1945 kepada Mahkamah Konstitusi adalah wewenang untuk menyelesaikan sengketa kewenangan lembaga negara (SKLN), yang kemudian pelaksanaannya diatur dalam Pasal 10 ayat (1) huruf b Undang-Undang Nomor 24 Tahun 2003 tentang Mahkamah Konstitusi sebagaimana telah diubah dengan Undang-Undang Nomor 8 Tahun 2011 tentang Mahkamah Konstitusi (selanjutnya disebut UU MK), yang berbunyi: "memutus sengketa kewenangan lembaga negara yang kewenangannya diberikan oleh UUD NRI Tahun 1945”, yang kemudian diatur dalam Peraturan Mahkamah Nomor 08/PMK/2006 tentang Pedoman Beracara Dalam Sengketa Kewenangan Konstitusional Lembaga Negara. Mahkamah Konstitusi memiliki kewenangan untuk memutus sengketa lembaga negara.

Mahkamah Konstitusi adalah lembaga negara yang termasuk salah satu pelaku kekuasaan kehakiman yang melakukan fungsi peradilan dalam menangani permasalahan ketatanegaraan berdasarkan otoritas

${ }^{7)}$ Zainal Arifin Mochtar, Lembaga Negara Independen, Dinamika Perkembangan dan Urgensi Penataannya kembali Pasca Amandemen Konstitusi, (Jakarta: Rajawali Pers, 2016), hal. 141. 
UUD 1945. ${ }^{8)}$ Sengketa kewenangan antar lembaga negara secara jelas memperoleh batasan bahwa lembaga negara tersebut hanyalah lembaga negara yang memperoleh kewenangannya menurut UUD NRI Tahun 1945, sehingga jelas meskipun dapat terjadi multitafsir dapat dilihat dalam UUD NRI Tahun 1945 lembaga negara mana yang memperoleh kewenangannya secara langsung dari UUD NRI Tahun 1945. Oleh karena UUD adalah juga mengatur organisasi negara dan wewenangnya masing-masing, maka kriteria yang dapat dikemukakan bahwa lembaga negara tersebut harus merupakan organ konstitusi yaitu baik yang dibentuk berdasarkan konstitusi maupun yang secara langsung wewenangnya diatur dan diturunkan dari UUD NRI Tahun $1945 .{ }^{9)}$

2. Tinjauan Umum mengenai Lembaga Negara

Istilah "lembaga-lembaga negara" dikukuhkan penggunaannya dalam Ketetapan No. XX/MPRS/ 1966 (lihat TAP MPR No. VI/MPR/1976 dan TAP MPR No. III/MPR/ 1978). Lembaga-lembaga negara yang dimaksud adalah Majelis Permusyawaratan Rakyat (MPR), Dewan Perwakilan Rakyat (DPR), Badan Pemeriksa Keuangan (BPK), Presiden, Dewan Pertimbangan Agung (DPA), dan Mahkamah Agung (MA). Sedang dalam Undang-undang nomor 24C tahun 2003 tentang Mahkamah Konstitusi Perubahan Ketiga UUD 1945, salah satu kewenangan MK yang ditentukan dalam Pasal 24C (1) UUD 1945 menjelaskan untuk memutuskan sengketa kewenanngannya antarlembaga Negara yang kewengannya diataur dalam UUD NRI Tahun $1945 .{ }^{10)}$

Lembaga Negara menurut UUD NRI tahun 1945 antara lain:

a. Majelis Permusyawaratan Rakyat (MPR)

Terdapat dua perubahan mendasar pada MPR setelah perubahan UUD, yaitu perubahan susunan keanggotaan serta perubahan

\footnotetext{
${ }^{8)}$ Ikhsan Rosyada Parluhutan Daulay, Mahkamah Konstitusi Memahami Keberadaannya dalam Sistem Ketatanegaraan Republik Indonesia, (Jakarta: PT Rineka Cipta, 2006), hal. 19.

${ }^{9)}$ Maruarar Siahaan, Hukum Acara Mahkamah Konstitusi RI, (Jakarta: Konpress, 2005), hal. 36 .

${ }^{10)}$ Arifin, Firmansyah dkk, Lembaga Negara dan Sengketa Kewenangan Antar Lembaga Negara, (Jakarta: Konsorsium Reformasi Hukum Nasional, 2005), hal. 3.
} 
kewenangan MPR, yang berimplikasi pada prubahan dalam tata hubungannya dengan lembaga-lembaga negara yang lainya. ${ }^{11)}$ Pertama, secara keanggotaan, kini keanggotaan MPR terdiri dari anggota DPR dan anggota DPD yang dipilih melalui pemilihan umum. Jika DPR dipilih melalui pemilu berbasis partai, DPD merupakan wakil dari daerah-daerah yang dipilih secara langsung dalam pemilu oleh rakyat didaerah yang bersangkutan. Berati secara total, keanggotaan 550 anggota DPR dan 132 anggota DPD. Kedua, implikasi pada kewenang. Filosofi kewenangan MPR, sebagimana tercermin dalam perubahan Pasal 1 ayat 2, yaitu "kedaulatan ditangan rakyat dan dijalankan menurut Undang-undang Dasar". Artinya, kewenangan MPR bukan lagi sebagai pelaksaan rakyat sepenuhnya karena kedaulatan rakyat dilaksanakan-menurut UUD NRI Tahun 1945 melalui lembagalembaga Negara. Kewenangan MPR dipertegas, yaitu pada ranah mengubah dan menetapkan UUD, melantik Presiden dan wakil Presiden, memberhetikan Presiden dan/atau wakil Presiden dalam masa jabatanya menurut UUD NRI Tahun 1945. MPR berwenang juga memilih wakil presiden dalam hal terjadi kekosongan jabatan wakil presiden dalam masa jabatannya. ${ }^{12)}$

b. Dewan Perwakilan Rakyat (DPR)

Perubahan ketiga UUD NRI Tahun 1945 telah menetapkan DPR dalam posisi sebagai lembaga negara lebih spesifik selain juga memiliki beberapa kewenangan. Dalam hal keanggotaan, anggota DPR dipilih melalui pemilihan umum dengan susunan yang diatur melalui UU. Hal tersebut menunjukan keanggotaan DPR mutlak melalui pemilihan dan tidak ada lagi yang melalui pengangkatan. Selain itu, DPR harus bersidang sedikitnya sekali dalam setahun. ${ }^{13)}$ Dalam kewenangnya, DPR memiliki kewenangan legislatif, yakni memegang kekuasaan membetuk UU. Konsekuensi dan implikasi dari

\footnotetext{
${ }^{11)}$ Ibid., hal. 72 .

${ }^{12)}$ Ibid., hal. 73 .

${ }^{13)}$ Ibid., hal. 74.
} 
pergeseran itu adalah DPR harus proaktif dalam proses pembentukan Undang-undang. Sikap proaktif tersebut diwujudkan antara lain dengan membentuk Badan Legislasi DPR yang khusus menangani masalah pembuatan Undang-Undang, selain penggunaan hak usul inisiatif DPR, baik oleh anggota-anggota maupun melalui komisi atau gabungan komisi. ${ }^{14)}$ DPR juga memiliki fungsi sebagai pengawas dengan hak yang dimiliki yaitu hak interpelasi, hak angket dan hak menyatakan pendapat.

c. Dewan Perwakilan Daerah (DPD)

DPD memiliki kedudukan yang sama dengan DPR sebagai lembaga perwakilan rakyat. Perbedaanya pada penekanan posisi anggota DPD sebagai wakil dan reppresentasi dari daerah (provinsi). Pembentukan DPD sebagai salah satu institusi Negara bertujuan member kesempatan kepada orang-orang daerah untuk ikut serta mengabil kebijakan dalam tinkat nasional, khususnya yang terkait dengan kepentingan daerah. ${ }^{15)}$ Dalam Undang-undang No. 12 Tahun 2003 telah mengatur dengan jelas bahwa anggota DPD berjumlah empat orang dari setiap provinsi. Pasal 22D dan 23F UUD NRI mengatur wewenang DPD : yaitu pertama, DPD dapat mengajukan kepada DPR rancangan undang-undang (RUU) yang kaitanya dengan otonomi daerah, hubungan pusat dan daerah, pembentukan, pemekaran, dan pengabungan daerah, pengolaan sumber daya alam dan sumber daya ekonomi lainya, serta ikut membahasnya. Kedua, DPD memberi pertimbangan kepada DPR atas RUU Anggaran Pendapan dan Belanja Negara, dan RUU yang kaitanya dengan Pajak, Pendidikan, dan Agama. Ketiga, DPD memberikan pertimbangan kepada DPR dalam pemilihan anggota Badan Pemeriksa Keungan. Keempat, DPD dapat melakukan pengawasan atas pelaksaan UU menenai otonomi daerah, pembentukan, pemekaran, dan

\footnotetext{
${ }^{14)}$ Ibid., hal. 74.

${ }^{15)}$ Ibid., hal. 75.
} 
penggabungan daerah, hubungan pusat dan daerah, pengelolaan sumber daya alam dan daya ekonomi lainya, pelaksaan Anggaran Pendapatan dan Belanja Negara, pajak, pendidikan, dan agama.

\section{d. Presiden dan Wakil Presiden}

Perubahan UUD NRI 1945 yang cukup signifikan dan mendasar bagi penyelenggaraan demokrasi yaitu pemilihan presiden dan wakil presiden secara langsung. Presiden dan wakil presiden dipilih secara langsung oleh rakyak melalui mekanisme pemilu. Pemilihan secara langsung presiden dan wakil presiden akan memperkuat legitimasi seorang presiden sehingga presiden diharapkan tidak mudah dihentikan ditengah jalan tanpa dasar memadai, yang bias mempengaruhi stabilitas politik dan pemerintahan secara aktual. ${ }^{16)}$

e. Mahkamah Agung

Kekuasaan kehakiman dalam sistem ketatanegaraan Indonesia bertujuan untuk menyelenggarakan peradilan yang merdeka, bebas dari intervensi pihak manapun, guna mengakan hukum dan keadilan. Kekuasaan kehakiman dilakukan oleh sebuah mahkamah agung dan badan badan peradilan yang berada dibawahnya dalam lingkungan peradilan umum, lingkungan peradilan agama, lingkungan peradilan militer, lingkungan peradilan tata usaha negaradan oleh sebuah makamah konstitusi. ${ }^{17)}$

Selain lembaga-lembaga yang sudah disebutkan di atas terdapat beberapa lembaga negara lainnya seperti Badan Pemeriksa Keuangan (BPK), Komisi Yudisial (KY), Pemeritah(-an) Daerah, Bank Sentral, Tentara Nasional Indonesia, Kepolisian Negara Republik Indonesia, Dewan Pertimbangan Presiden. Tinjauan Umum Mengenai Pengangkatan Anggota Legislatif Daerah. 


\section{Tinjauan Umum Pimpinan DPD-RI}

Salah satu alat kelengkapan DPD-RI adalah pimpinan yang merupakan satu kesatuan pimpinan yang bersifat kolektif-kolegial. Pimpinan terdiri atas satu orang ketua dan dua orang wakil ketua yang dipilih dari dan oleh anggota DPD-RI dalam sidang paripurna. Setelah terpilih, ketua dan wakil ketua terpilih tersebut diresmikan dengan keputusan DPD-RI. ${ }^{18)}$ Pimpinan DPD-RI dipilih dengan menjunjung tinggi prinsip mencerminkan keterwakilan kepulauan dalam Negara Kesatuan Republik Indonesia dan juga prinsip mencerminkan keterwakilan wilayah. ${ }^{19)}$

Pimpinan DPD tidak memiliki wewenang untuk mengeluarkan pernyataan politik atas nama DPD atau jabatannya, kecuali ditugaskan oleh DPD. Selain itu, pimpinan DPD berwenang bertindak atas nama DPD-RI hanya dalam hal-hal yang bersifat protokoler. Pimpinan tidak dapat membatalkan hasil keputusan alat kelengkapan DPD yang telah menjadi keputusan pada pembicaraan tingkat $\mathrm{I}^{20)}$

\section{Pembahasan}

\section{A. Kronologi Kasus}

Berkaitan dengan permasalahan yang penulis angkat, menceritakan kronologi kasus permasalahan dirasa cukup penting agar membantu dalam hal ini pembaca menjadi lebih mengerti tentang kasus yang penulis angkat.

${ }^{21)}$ Dewan Perwakilan Daerah (DPD), kumpulan para senator yang maju mewakili daerahnya masing-masing kemarin, Selasa (4/4/2017) memperlihatkan tabiat keras dan tak ragu berkonflik. Melakukan rapat

\footnotetext{
${ }^{18)}$ M Yusuf, Dewan Perwakilan Daerah Republik Indonesia, (Yogyakarta: Graha Ilmu, 2013), hal. 49.

${ }^{19)}$ Ibid., hal. 49.

${ }^{20)}$ Ibid., hal. 49.

${ }^{21)}$ John Andhi Oktaveri, "Kronologi Hingga OSO Dilantik Jadi Ketua DPD", www.kabar24.bisnis.com, diakses tanggal 12 Mei 2018.
} 
paripurna sejak Senin, DPD akhirnya terbelah antara kubu yang menginginkan hadirnya pimpinan baru dan pihak yang menilai pemilihan pimpinan baru cacat hukum karena tak sesuai putusan MA.

Rapat paripurna DPD Senin (3/4) malam sempat diwarnai kericuhan. Seorang anggota DPD yang melakukan protes dan naik ke podium, didorong hingga terjatuh oleh anggota DPD lainnya. Rekaman adegan itu pun nampak disiarkan stasiun televisi. Pada akhirnya, rapat paripurna memilih Ketua DPD. Oesman Sapta Odang alias OSO terpilih sebagai Ketua DPD yang baru. Terpilihnya OSO disambut gembira para pendukungnya, namun di sisi lain memancing keprihatinan kubu lain serta kecaman dari pengamat.

Pemilihan pimpinan Dewan Perwakilan Daerah (DPD) yang menetapkan Oesman Sapta Odang (OSO) sebagai ketua didampingi dua wakil masing-masing Darmayanti Lubis dan Nono Sampono pada Selasa (4/4/2017) dini hari merupakan tindakan ilegal dan inkonstitusional. Demikian pendapat pengamat Hukum Tata Negara Irmanputra Sidin ketika diminta tanggapannya atas pemilihan pimpinan lembaga tinggi negara yang penuh kontroversi tersebut. Menurut Irman Gusman, alasan tidak sahnya kepemimpinan baru tersebut karena Mahkamah Agung (MA) telah mengeluarkan putusan yang memenangkan gugatan bahwa periode kepemimpinan DPD adalah lima tahun, yakni 2014 hingga 2019. Artinya, masa kepemimpinan di lembaga perwakailan daerah itu bukan 2,5 tahun sebagaimana diatur Tata Tertib lembaga tersebut. "Tidak ada lagi dasar hukum yang bisa memotong masa jabatan Ratu Hemas dan Mohammad Farouq. Kalau ada pemilihan pimpinan DPD semalam yang kemudian mengganti kedudukan keduanya maka Itu adalah pemilihan ilegal dan konstitusional," ujar Irman Selasa (4/4/2017).

Ratu Hemas dan Farouq merupakan paket pimpinan DPD hasil pemilihan periode 2014-2019 dengan ketua Irman Gusman. Akan tetapi, karena Irman Gusman terjerat kasus pidana memperdagangkan pengaruh maka jabatannya digantikan senator asal Bengkulu, Muhammad Saleh 
berdasarkan hasil rapat paripurna DPD tiga bulan lalu yang juga kontroversial.

Menurut Tata Tertib yang disepakati DPD, Saleh dipilih jadi ketua hingga April ini untuk menghabiskan masa jabatan Irman yang tersisa dan untuk selanjutnya dilakukan pemilihan ketua baru.“Jadi pemilihan pimpinan DPD semalam tidak mengganggu legalitas Hemas dan Farouq," ujar Irman. Lebih jauh dosen Hukum Tata Negara tersebut menjelaskan bahwa segala tindakan yang terkait dengan tindakan ketatanegaraan yang dijalankan pimpian DPD yang baru, juga ilegal dan inkonstitusional. Di antara tugas tersebut termasuk dalam hal pelagggaran, legislasi, dan dalam hal protokoler kenegaraan. Wakil Ketua DPD Farouk Muhammad menyatakan bahwa dirinya masih tetap menjadi pimpinan DPD. Terkait pernyataannya itu, dia menyesalkan bahwa proses pemilihan pimpinan lembaga tinggi negara dilakukan pada sidang paripurna DPD tidak sah. Dalam sidang itu Oesman Sapta Odang (OSO) terpilih sebagai Ketua DPD didampingi oleh masingmasing wakil ketua, yakni Nono Sampono dan Darmayanti Lubis. Menurutnya, pemilihan pimpinan itu bertentangan dengan peraturan perundang-undangan yang lebih tinggi. Setelah Ketua DPD periode 20142019 Irman Gusman diberhentikan dari jabatannya karena terlibat kasus korupsi dalam skandal impor gula, pimpinan DPD dipegang Muhammad Saleh sebagai ketua didampingi GKR Hemas dan Farouk yang masingmasing menjabat wakil ketua. "Ini memprihatinkan karena menyangkut lembaga yang saya pimpin. Lebih-lebih lagi proses dilakukan secara brutal sehingga terjadi kegaduhan dalam Sidang Paripurna dan dinilai publik sebagai perbuatan yang memalukan," ujarnya kepada wartawan, Selasa (4/4/2017).

Menurut Farouq, dirinya masih tetap mengemban amanah jabatan sebagai Wakil Ketua DPD yang didasarkan atas Keputusan DPD Nomor 02/DPD RI/I/2014-2015 untuk masa jabatan 2014-2019. Masa jabatan tersebut dikuatkan oleh Putusan MA Nomor 38P/HUM/2016 dan Nomor 20P/HUM/2017, ujarnya. Lebih jauh dia mengatakan bahwa putusan MA itu 
membatalkan dua Tata Tertib DPD (Nomor 1 Tahun 2016 dan Nomor 1 Tahun 2017) yang salah satunya mengubah masa jabatan Pimpinan DPD dari 5 tahun ke 2,5 tahun dan dinyatakan bertentangan dengan UU MD3 dan UU P3 sehingga dipandang tidak sah dan mengikat. Menurut Farouk, kalau MA tetap melakukan pelantikan pejabat baru maka lembaga itu telah mengingkari amar putusannya sendiri sekaligus mencerminkan runtuhnya benteng terakhir penegakan hukum di Republik tercinta. Wakil Ketua Bidang Non Yudisial Mahkamah Agung Suwardi akhirnya melantik dan mengambil sumpah Oesman Sapta Oedang (OSO) sebagai Ketua DPD RI periode April 2017-September 2019.

Pelantikan tersebut sekaligus untuk dua Wakil Ketua DPD Nono Sampono dan Darmayanti Lubis dalam sidang paripurna DPD malam ini, Selasa (4/4/2017). "Demi Allah saya bersumpah, bahwa saya akan memenuhi kewajiban saya sebagai Ketua DPD dengan sebaik-baiknya dan seadil-adilnya sesuai peraturan perundang-undangan dengan berpedoman kepada Pancasila dan UUD 1945," ujar OSO mengucap sumpah jabatan yang dipandu Suwardi, di Gedung Nusantara V, Kompleks Parlemen. Pelantikan itu dilakukan berdasarkan keputusan DPD nomor: 45/DPDRI/III/2016-2017 tentang pimpinan DPD RI periode April 2017 September 2019. Keputusan ini mencabut keputusan sebelumnya tentang pimpinan DPD nomor 02/DPD/I/2014-2105 dan nomor 09/DPD/I/20162019. Pelantikan yang dihadiri sejumlah anggota DPD berjalan lancar. Usai pengambilan sumpah jabatan dan pelantikan, pimpinan sidang AM Fatwa menyerahkan palu sidang kepada OSO. "Kami ucapkan selamat kepada pimpinan DPD. Jaga amanat yang telah diberikan kepada senator," ujar Fatwa. Selanjutnya OSO memimpin sidang dan menyatakan harapannya agar setiap senator bekerja fokus dan memaksimalkan energi untuk kepentingan bangsa.

\section{B. Penyelesaian Sengketa Lembaga Negara}

Untuk menyelesaikan sengketa yang mana dalam hal ini mengenai sengketa lembaga negara, peraturan perundang-undangan memberikan 
beberapa opsi pilihan atau jalan yang dapat ditempuh sebagai sarana penyelesaian atas permasalahan yang dihadapi.

“Termasuk dalam prinsip negara hukum yakni adanya supremasi hukum yang meyakini pemimpin tertinggi ialah konstitusi yang diikuti oleh adanya persamaan dalam hukum, menjunjung asas legalitas, adanya pembatasan kekuasaan, peradilan yang bebas dan tidak memihak, adanya Peradilan Tata Usaha Negara, adanya Peradilan Tata Negara seperti Mahkamah Konstitusi, adanya perlindungan Hak Asasi Manusia (HAM), menganut sifat demokratis dimana kekuasaan berada ditangan rakyat, mempunyai tujuan dalam bernegara, serta adanya transparasi dan kontrol sosial.",22)

Cara yang dapat ditempuh untuk menyelesaikan sengketa lembaga negara antara lain dapat melalui Mahkamah Agung (MA), Mahkamah Konstitusi (MK), dan Peradilan Tata Usaha Negara (PERATUN).

1. Mahkamah Agung (MA)

Sebelum lahir UU No. 14 Tahun 2008 tentang Keterbukaan Informasi Publik, Mahkamah Agung adalah salah satu lembaga yang sudah lebih dahulu punya payung hukum keterbukaan informasi. Dalam semangat keterbukaan, Mahkamah Agung bisa dibilang mendahului banyak lembaga negara lainnya, reformasi pelaku kekuasaan kehakiman ini terus berproses hingga kini. ${ }^{23)}$ Pada Mei 1998 di Indonesia terjadi perubahan politik yang radikal dikenal dengan lahirnya Era Reformasi. Konsep Peradilan Satu Atap dapat diterima yang ditandai dengan lahirnya TAP MPR No. X/MPR/1998 yang menentukan Kekuasaan Kehakiman bebas dan terpisah dari Kekuasaan Eksekutif. Ketetapan ini kemudian dilanjutkan dengan diundangkannya Undang-Undang Nomor 35 Tahun 1999 tentang Perubahan atas Undang-Undang Nomor 14 Tahun 1970 tentang ketentuan-ketentuan Pokok Kekuasaan Kehakiman. Pada tanggal 23 Maret 2004 lahirlah Keputusan Presiden Republik

\footnotetext{
${ }^{22)}$ Jimly Asshiddiqie, Konstitusi dan Konstitusionalisme Indonesia, Cetakan ke-2. (Jakarta: Sinar Grafika, 2011), hal. 127. 2018 .

${ }^{23)}$ Muhammad Yasin, "Mahkamah Agung", hukumonline.com, diakses tanggal 15 April
} 
Indonesia Nomor 21 Tahun 2004 tentang pengalihan organisasi, administrasi dan finansial dan lingkungan Peradilan Umum dan Tata Usaha Negara, Pengadilan Agama ke Mahkamah Agung, yang ditindaklanjuti dengan serah terima Pengalihan organisasi, administrasi dan finansial di lingkungan Peradilan Umum dan Peradilan Tata Usaha Negara dari Departemen Kehakiman dan HAM ke Mahkamah Agung pada tanggal 31 Maret 2004.

Mahkamah Agung memiliki wewenang:

a. Mahkamah Agung memutus permohonan kasasi terhadap putusan pengadilan tingkat banding atau tingkat terakhir dari semua lingkungan peradilan.

b. Mahkamah Agung menguji peraturan secara materiil terhadap peraturan perundang-undangan di bawah Undang-undang.

c. Melakukan pengawasan tertinggi terhadap penyelenggaraan peradilan di semua lingkungan peradilan dalam penyelenggaraan kekuasaan kehakiman.

2. Mahkamah Konstitusi (MK)

Setelah disahkannya Perubahan Ketiga UUD 1945 maka dalam rangka menunggu pembentukan MK, MPR menetapkan Mahkamah Agung (MA) menjalankan fungsi MK untuk sementara sebagaimana diatur dalam Pasal 3 aturan peralihan UUD 1945 hasil perubahan keempat, DPR dan Pemerintah kemudian membuat Rancangan UndangUndang mengenai Mahkamah Konstitusi, setelah melalui pembahasan mendalam, DPR dan Pemerintah menyetujui secara bersama UU Nomor 24 Tahun 2003 tentang Mahkamah Konstitusi pada 13 Agustus 2003 dan disahkan oleh Presiden pada hari itu (Lembaran Negara Nomor 98 dan Tambahan Lembaran Negara Nomor 4316), dua hari kemudian, pada tanggal 15 Agustus 2003, Presiden melalui Keputusan Presiden Nomor 147/M Tahun 2003 hakim konstitusi untuk pertama kalinya yang dilanjutkan dengan pengucapan sumpah jabatan para hakim konstitusi di Istana Negara pada tanggal 16 Agustus 2003. 
Lembaran perjalanan MK selanjutnya adalah pelimpahan perkara dari MA ke MK, pada tanggal 15 Oktober 2003 yang menandai mulai beroperasinya kegiatan MK sebagai salah satu cabang kekuasaan kehakiman menurut ketentuan UUD 1945.Wewenangan Mahkamah Konstitusi telah diatur dalam pasal 24 ayat (1) dan (2) UUD 1945. Mahkamah Konstitusi berwenang untuk melakukan peradilan pada tingkat pertama dan terakhir yang putusannya bersifat final untuk:

a. Menguji Undang-Undang Terhadap UUD NRI Tahun 1945.

Kewenangan yang paling penting dari keempat kewenangan yang harus dilaksanakan oleh MK (Mahkamah Konstitusi) menurut Undang-Undang Dasar Negara Republik Indonesia Tahun 1945 adalah kewenangan untuk melakukan pengujian konstitusi undangundang. maka dari keempat kewenangan tersebut, yang dapat dikatakan paling banyak mendapat sorotan di dunia ilmu pengetahuan adalah pengujian atas konstitusi Undang-undang.

b. Memutuskan Sengketa Pendapat

Mengenai hal sengketa dalam segala hal kewenangan lembaga konstitusi negara adalah adanya perbedaan pendapat atau pemikiran yang disertai persengketaan lainnya terhadap kewenangan setiap lembaga negara itu. Hal ini bisa terjadi mengingat sistem hubungan antara satu lembaga dengan lembaga lainnya menganut prinsip check and balances, yang berarti sederajat tetapi saling mengendalikan satu dengan yang lainnya. Sebagai akibat dari hubungan tersebut, dalam melaksanakan kewenangan masing-masing lembaga timbul kemungkinan terjadinya perselisihan. Mahkamah Konstitusi dalam perkara ini, akan menjadi hakim yang akan mengadili dengan seadiladilnya. Dan kewenangan ini juga telah diatur dalam Pasal 61 -67 UU No. 24 Tahun 2003.

c. Memutuskan Pembubaran Partai Politik

Kebebasan Partai politik dalam berpartai adalah cerminan kebebasan manfaat organisasi dalam masyarakat dan bernegara untuk 
berserikat yang dijamin dalam Pasal 28 ayat (3) UUD 1945. Oleh sebab itu, setiap orang sesuai dengan ketentuan UU bebas mendirikan dan ikut serta dalam kegiatan parpol. Karena itu, pembubaran parpol bukan oleh anggota partai politik yang bersangkutan merupakan tindakan yang bertentangan dengan konstitusi atau inkonstitusional. Untuk adanya jaminan perlindungan terhadap prinsip kebebasan berserikat itulah maka disediakan cara pembubaran suatu partai politik yang diwajibkan untuk ditempuh melalui prosedur dari konstitusi yang berlaku. Yang diberi hak "berdiri" untuk menjadi pemohon dalam suatu perkara pembubaran partai politik adalah Pemerintah, bukan orang perorang atau sekelompok orang. Yang berwenang memutuskan benar tidaknya hal-hal yang dijadikan alasan tuntutan pembubaran partai politik adalah Mahkamah Konstitusi.

d. Memutuskan Perselisihan Tentang Hasil Pemilu

Berdasarkan Pasal 22 ayat (2) UUD 1945, pemilihan umum memiliki tujuan untuk memilih presiden dan wakil presiden, anggota Dewan Perwakilan Rakyat, Dewan Perwakilan Rakyat Daerah. Peserta Pemilihan Umum itu ada tiga, yaitu pertama, pasangan calon presiden/wakil presiden, kedua, partai politik peserta pemilihan umum anggota DPR dan DPRD, dan ketiga, (perorangan calon anggota Dewan Perwakilan Daerah (DPD). Sedangkan penyelenggara pemilihan umum adalah Komisi Pemilihan Umum yang diawasi oleh Panitia Pengawas Pemilihan Umum (PANWASLU) sebagaimana yang telah berlaku dalam sistem pemilu di indonesia saat ini. Apabila timbul perselisihan pendapat antara peserta pemilihan umum dengan penyelenggara pemilihan umum, dan perselisihan itu tidak dapat diselesaikan sendiri oleh para pihak, maka hal itu dapat diselesaikan melalui proses peradilan di Mahkamah Konstitusi. Pokok yang menjadi permasalahan yang memang harus segera diselesaikan di Mahkamah Konstitusi adalah soal perselisihan perhitungan pendapatan suara pemilihan umum yang telah ditetapkan dan 
diumumkan secara nasional oleh KPU melalui struktur organisasi pemerintahan dikota,kabupaten maupun struktur organisasi pemerintahan desa yang menjadi panitia pemilu, dan selisih perolehan suara dimaksud berpengaruh terhadap kursi yang akan diperebutkan. Jika terbukti bahwa selisih peroleh suara itu tidak mempengaruhi peroleh kursi yang diperebutkan, maka perkara yang dimohonkan akan dinyatakan tidak dapat diterima. Jika selisih yang dimaksud memang berpengaruh, dan bukti-bukti yang telah diajukan sangat kuat dan beralasan, maka permohonan dikabulkan dan perolehan suara yang benar ditetapkan oleh Mahkamah Konstitusi sehingga perolehan kursi yang diperebutkan akan jatuh ke tangan pemohon yang permohonannya dikabulkan. Sebaliknya, jika permohonan tidak beralasan atau bukti-bukti yang diajukan tidak terbukti benar, maka permohonan pemohon akan ditolak. Ketentuan-ketentuan ini berlaku baik untuk pemilihan anggota DPR, DPD, DPRD, maupun untuk pasangan Calon Presiden/Calon Wakil Presiden.

e. Memutuskan Pendapat DPR Mengenai Dugaan Pelanggaran Oleh Presiden dan Wakil Presiden

Memutuskan segala pemasalahan sengketa penuntutan pertanggung jawaban presiden atau wapres dalam istilah resmi UUD 1945 diberikan sebagai kewajiban Mahkamah Konstitusi untuk memutuskan pendapat DPR bahwa Presiden maupun Wapres telah melakukan pelanggaran hukum negara yaitu pengkhianatan terhadap negara, melakukan tindakan korupsi yang memiliki dampak korupsi bagi negara dan masyarakat, dan lain sebagainya. Atau perbuatan tercela yang menyebabkan presiden atau Wapres tidak lagi memenuhi syarat menjadi Presiden dan Wakil presiden menurut UUD dan juga meninggalkan tugas,fungsi, dan wewenang presiden dan wakil presiden. Maka Mahkamah Konstitusi memiliki kewajiban untuk memberikan putusan atas opini atau pendapat DPR bahwa presiden dan/atau Wakil Presiden diduga melakukan perkara pelanggaran 
hukum seperti, penghianatan terhadap negara sendiri, korupsi, penyuapan, tindakan pidana lainnya dan juga perbuatan tercela yang menyebabkan presiden dan wakil presiden tidak lagi memenuhi persyaratan seperti dalam UUD 1945.

\section{Peradilan Tata Usaha Negara (PERATUN)}

Peradilan Tata Usaha Negara (PERATUN) merupakan lingkungan peradilan yang terakhir dibentuk, yang ditandai dengan disahkannya Undang-Undang Nomor 5 Tahun 1986 pada tanggal 29 Desember 1986, adapun tujuan dibentuknya Peradilan Tata Usaha Negara (PERATUN) adalah untuk mewujudkan tata kehidupan negara dan bangsa yang sejahtera, aman, tenteram serta tertib yang dapat menjamin kedudukan warga masyarakat dalam hukum dan menjamin terpeliharanya hubungan yang serasi, seimbang, serta selaras antara aparatur di bidang tata usaha negara dengan para warga masyarakat. Terbentuknya Peradilan Tata Usaha Negara (PERATUN) menjadi bukti bahwa Indonesia adalah negara hukum yang menjunjung tinggi nilai-nilai keadilan, kepastian hukum dan Hak Asasi Manusia $(\mathrm{HAM}){ }^{24)}$ Berdasarkan Peraturan Pemerintah Nomor 7 Tahun 1991 pada tanggal 14 Januari 1991, Peradilan Tata Usaha Negara (PERATUN) resmi beroperasi, salah satunya adalah Pengadilan Tata Usaha Negara Jakarta yang berkedudukan di ibukota Kabupaten/Kota, dengan daerah hukumnya meliputi wilayah Kabupaten/Kota.

Pengadilan Tata Usaha Negara mempunyai tugas dan wewenang yaitu "memeriksa, memutus dan menyelesaikan sengketa Tata Usaha Negara, yaitu suatu sengketa yang timbul dalam bidang hukum TUN antara orang atau badan hukum perdata (anggota masyarakat) dengan Badan atau Pejabat TUN (pemerintah) baik dipusat maupun didaerah sebagai akibat dikeluarkannya suatu Keputusan TUN (beschikking),

${ }^{24)}$ Rozali Abdullah, Hukum Acara Peradilan Tata Usaha Negara, Cetakan ke-12. (Jakarta: PT Rajagrafindo Persada, 2013), hal. 12. 
termasuk sengketa kepegawaian berdasarkan peraturan perundangundangan yang berlaku. Maka dapat disimpulkan bahwa yang menjadi Subjek di Peradilan Tata Usaha Negara (PERATUN) adalah Seseorang atau Badan Hukum Perdata sebagai Penggugat, dan Badan atau Pejabat Tata Usaha Negara sebagai Tergugat. Sedangkan yang menjadi Objek di Peradilan Tata Usaha Negara (PERATUN) adalah Surat Keputusan Tata Usaha Negara (beschikking).

Sudah terbilang hampir satu bulan trio Oesman Sapta, Nono Sampono, dan Darmayanti Lubis duduk di singgasana tampuk pimpinan Dewan Perwakilan Daerah. Meski prosesnya dinilai banyak orang ilegal, setidaknya dalam kacamata ahli hukum tata negara yang terhimpun dalam Asosiasi Pengajar Hukum Tata Negara dan Hukum Administrasi Negara (APHTN-HAN), gonjang-ganjing tentang pemilihan itu mulai meredup. Salah satu tujuan negara hukum yaitu untuk memastikan adanya suatu kepastian hukum atas semua hal yang terjadi. Berdasarkan permasalahan yang peneliti bahas, belum terdapat adanya payung hukum yang dapat dijadikan pedoman dalam memutus sengketa internal lembaga negara dalam hal ini para pihak yang bersengketa.

Sebenarnya permasalahan awal dimulai ketika Tata Tertib DPD yang mengatur masa jabatan pimpinan DPD menjadi 2,5 tahun disahkan, hal ini tentu bertentangan dengan Undang-Undang Nomor 17 tahun 2014 khususnya pasal 260 ayat (1) yang berbunyi "Ketentuan lebih lanjut mengenai tata cara pemilihan pimpnan DPD diatur dalam peraturan DPD tentang tata tertib". Berdasarkan pernyataan itu seharusnya sudah jelas bahwa Tata Tertib itu hanya mengatur tata cara pemilihan dan bukan mengatur tentang masa jabatan pimpinan. Begitu pula dengan pemberlakuan surut masa jabatan pimpinan yang tadinya 5 (lima) tahun atau sesuai dengan siklus pemilu menjadi 2,5 tahun sesungguhnya itu telah melanggar Undang-Undang Nomor 12 tahun 2011 yang melarang adanya pemberlakuan surut. Sesungguhnya Mahkamah Agung telah 
mengeluarkan putusan tentang permbatalan Tata Tertib Nomor 1 tahun 2017 tersebut, akan tetapi Mahkamah Agung tetap melantik pimpinan DPD yang baru. Mahkamah Agung beralasan bahwa dalam pasal 260 ayat (3) Undang-Undang MD3 menegaskan bahwa Ketua Mahkamah Agung berperan memandu pengucapan sumpah atau janji Pimpinan DPD. Mahkamh Agung dalam hal ini telah melakukan ambivalensi atau ambigu dalam bersikap, disatu sisi Mahkamah Agung dalam putusannya menolak Tata Tertib DPD yang menyatakan masa jabatan pimpinan selama 2,5 tahun tetapi di lain sisi Mahkamah Agung tetap melantik pimpinan baru DPD hasil dari dasar hukum yang dibatalkan sendiri oleh Mahkamah Agung. Rasanya tidak etis apabila suatu pimpinan lembaga negara yang sudah ditetapkan masa jabatannya oleh suatu peraturan perundang-undangan yaitu selama 5 (lima) tahun atau sesuai dengan siklus pemilihan umum tiba-tiba diberhentikan dan dipotong masa jabatannya menjadi 2,5 tahun dengan menggunakan dasar hukum yang sudah dibatalkan oleh Mahkamah Agung.

Mengutip pendapat dari Muhammad Abudan. S.H., M.H sebagai Dosen fakultas hukum bahwa permasalahan awalnya ini disebabkan oleh Mahkamah Agung, hal tersebut dikarenakan tindakan Mahkamah Agung yang melakukan pelantikan terhadap pimpinan DPD yang baru. Pelantikan yang dilakukan oleh Mahkamah Agung inilah yang membuat pimpinan DPD yang baru seakan-akan menjadi sah secara hukum. Hal tersebut dikarenakan Mahkamah Agung merupakan lembaga terkuat dalam memberikan suatu keabsahan, namun tindakan melantik tersebut membuat Mahkamah Agung melanggar peraturan yang di buatnya sendiri.

\section{Penutup}

\section{A. Kesimpulan}

Berdasarkan hasil pembahasan yang telah diuraikan pada bab-bab sebelumnya, penulis berkesimpulan bahwa Indonesia sebagai negara hukum 
sudah sepatutnya menjunjung tinggi asas kepastian hukum. Permasalahan yang terjadi sebenarnya sederhana tetapi akan berakibat fatal apabila dibiarkan, seperti dalam kasus yang penulis angkat apabila terjadi kembali di lembaga negara lain. Untuk menyelesaikan sengketa lembaga negara sebenarnya dapat diajukan ke Mahkamah Konstitusi tetapi permasalahan yang kemudian muncul adalah adanya kata "antar lembaga negara", dengan kata lain untuk menyelesaikan sengketa internal lembaga negara belum diatur sampai dengan saat ini. Selama ini kerap dipahami bahwa sengketa kewenangan harus melibatkan sedikitnya dua lembaga negara yang kewenangannya diberikan konstitusi.

Pasal 24C UUD 1945 sendiri hanya menyebut sengketa kewenangan lembaga negara, bukan sengketa kewenangan antarlembaga negara. Artinya, konflik internal lembaga sebagaimana yang membelit DPD seharusnya dapat pula dibawa ke MK untuk diselesaikan. Penyelesaian oleh MK akan jauh lebih efektif dan efisien jika dibandingkan dengan penyelesaian oleh lembaga peradilan non-MK, yang sering harus bertingkat-tingkat. Soalnya, apakah MK mau menyambut tanggung jawab ini.

Penulis berpendapat dalam hal ini bahwa pangkal permasalahan yang terjadi sebenarnya bermula dari Mahkamah Agung yang tetap melantik pimpinan yang baru menggantikan pimpinan yang lama dengan menggunakan dasar hukum yang telah dibatalkan sendiri oleh Mahkamah Agung, berarti dalam hal ini Mahkamah Agung telah ambigu dalam bertindak. Apabila melalui peradilan seperti Pengadilan Negeri dan Peradilan Tata Usaha Negara maka akan timbul pertanyaan seperti apakah peradilan di bawah Mahkamah Agung berani untuk mengoreksi tindakan yang dilakukan oleh Mahkamah Agung.

Penulis berkesimpulan dalam menyelesaikan sengketa internal lembaga negara, pemerintah harus segera menerbitkan aturan baru mengenai permasalahan tersebut, hal tersebut bertujuan untuk mencegah kesewenangwenangan seperti dalam hal pimpinan DPD terjadi di lembaga negara lain. Untuk sengketa internal yang terjadi di DPD, penulis berpendapat sebaiknya 
harus tetap dilakukan langkah hukum apapun bentuknya atau lebih tepatnya harus ada suatu terobosan hukum agar adanya perlawanan terhadap kesewenang-wenangan dalam pelantikan pimpinan DPD

\section{B. Saran}

Permasalahan sebagaimana dijelaskan sebelumnya menandakan bahwa Indonesia sebagai negara hukum belum sepenuhnya menjamin kepastian hukum yang dibuktikan dengan masih tidak adanya aturan yang mengatur mengenai masalah sengketa internal lembaga negara. Sebagai masyarakat Indonesia, tentunya diketahui bahwa hukum yang terdapat di Indonesia sudah ada sejak lama, akan tetapi sampai sekarang belum banyak pembaharuan yang dilakukan atas hukum tersebut. Saran penulis, alangkah baiknya peraturan hukum yang ada di Indonesia untuk segera diperbaharui atau dimodernisasi setidaknya untuk terus selalu mengikuti perubahan zaman.

\section{Daftar Pustaka}

\section{A. Buku}

Firmansyah, Arifin. Lembaga Negara dan Sengketa Kewenangan Antarlembaga Negara, (Jakarta: Konsorsium Reformasi Hukum Nasional, 2005).

Sunggono, Bambang. Metodologi Penelitian Hukum. (Jakarta: Raja Grafindo, 2003).

Rosyada, Parluhutan Daulay Ikhsan. Mahkamah Konstitusi Memahami Keberadaannya dalam Sistem Ketatanegaraan Republik Indonesia, (Jakarta: PT Rineka Cipta, 2006).

Asshiddiqie, Jimly. Konstitusi dan Konstitusionalisme Indonesia. Cetakan ke-2. (Jakarta: Sinar Grafika, 2011).

Siahaan, Maruarar. Hukum Acara Mahkamah Konstitusi RI, (Jakarta: Konpress, 2005).

Yusuf, M. Dewan Perwakilan Daerah Republik Indonesia. (Yogyakarta: Graha Ilmu, 2013).

Mahmud, Marzuki Peter. Penelitian Hukum. Cetakan ke-8. (Jakarta: Kencana, 2013).

Soekanto, Soerjono. Pengantar Penelitian Hukum. (Jakarta: Universitas Indonesia, 2006). 
Hartono, Sunaryati. Penelitian Hukum di Indonesia Pada akhir Abad ke-20.

(Bandung: Alumni, 1994).

B. Wawancara

Abudan, Muhammad. Wawancara dengan penulis. Fakultas Hukum Universitas Tarumanagara, 21 Mei 2018.

\section{Peraturan Perundang-Undangan}

Indonesia. Undang-Undang Dasar Negara Republik Indonesia Tahun 1945.

- Undang-Undang Nomor 12 Tahun 2011 tentang Pembentukan Peraturan Perundang-Undangan (Lembaran Negara Republik Indonesia Tahun 2011 Nomor 82, Tambahan Lembaran Negara Republik Indonesia Nomor 5234).

. Undang-Undang Nomor 17 Tahun 2014 tentang Majelis Permusyawaratan Rakyat, Dewan Perwakilan Rakyat, Dewan Perwakilan Rakyat Daerah, dan Dewan Perwakilan Daerah (Lembaran Negara Republik Indonesia Tahun 2014 Nomor 182, Tambahan Lembaran Negara Republik Indonesia Nomor 5568).

D. Artikel

Muhammad Yasin, "Mahkamah Agung", hukumonline.com, tanggal 15 April 2018.

Rakhmat Nur Hakim, "Yusril Anggap Sah Kepemimpinan Oesman Sapta di DPD", www.nasional.kompas.com, tanggal 13 Mei 2018.

John Andhi Oktaveri, "Kronologi Hingga OSO Dilantik Jadi Ketua DPD", www.kabar24.bisnis.com, diakses tanggal 12 Mei 2018. 